\title{
Quantitative analysis of the Income, Mental Health Effect of SARS COV-2 Pandemic in Calabar
}

\author{
Pius U. Angioha ${ }^{\mathrm{a},}$, James A. Ogar ${ }^{\mathrm{a}}$, Eworo E. Eteng ${ }^{\mathrm{a}}$, Godwin E. Okpiliya ${ }^{\mathrm{a}}$, Gbadebo S. Maruf ${ }^{\mathrm{b}}$, \\ Abayomi Akintola $^{\mathrm{a}}$ \& Francis E. Ibioro ${ }^{\mathrm{a}}$ \\ ${ }^{a}$ University of Calabar, P.M.B.115 Cross River State, Nigeria \\ ${ }^{b}$ School of Business Management, Universiti Utara Malaysia, Sintok, Kedah, Malaysia
}

\begin{abstract}
The novel SARS-COV-2 pandemic known as coronavirus (covid-19) pandemic has had such an impact that it has changed the way human behaves. Its impact has been felt in all sphere of human life. This study examines the extent to which the covid-19 pandemic has affected the socio-economic life of the people in Calabar, Cross River State, Nigeria. The survey research design was adopted in collecting data from 400 respondents from Calabar using cluster, purposive and simple random sampling technique. A self-developed questionnaire was used as the instrument of data collection. Descriptive statistics was used to analyse the data collected from the field. The result from descriptive analysis was also subjected to parametric statistics. Out of the 400 hundred instruments distributed 379 was returned and used for analysis. Result revealed that 89.2 percent report reduced income. 83.6 percent reported suffering as a result of income loss. 25.9 percent suffered from mental health issues. 14.2 percent reported needing to see a doctor. From the parametric statistics carried out, result revealed a significant correlation between covid-19 pandemic and family income and mental health. The study concludes that the covid-19 pandemic has significant impact in the life of people in Calabar. Based on this finding, there is a need for government to implement changes in social security programmes as well as provide guidance and advice for health workers and general public etc.
\end{abstract}

Keywords: SARS-COV-2; Income; Calabar; Calabar

\section{Introduction}

The severe respiratory syndrome coronavirus -2 , generally known as Corvid 19 , emanated from the Chinese province of Wuhan on December 8, 2019, has since been recognised as a global health emergency by the World Health Organization, with an increasing fatality rate (WHO, 2020; Maralidar, Anibi, Sekaram, Krisharm, 2020). The virus which causes Pneumonia like Symptom is a member of the germs Coronavirsdaie (Amawi, Abu Deiab, Aljabali, Dua and Tambuwala, 2020, Binns, Low and Kyung, 2020). The pandemic has become more than a health crisis. It has affected and created long-lasting social, economic and political devastation. Its effect will remain long after the Pandemic (Omang, Angioha, Ojong-Ejoh \& Abang, 2020, Akinbola Angioha, Abang, Etta, 2020). United Nations, 2020). It has become the most significant challenges the world has faced since the second world war and continues to throw several challenges to different nation (Karasmanaki \&Tsantopoulos, 2021). As of January 28, 2021, only fifteen Nations globally have not reported any Virus cases (World Health Organization, 2021).

As of February 2021, there were 103 million cases, with 2.24 million deaths globally. To curb the spread of the virus, the government of affected nations have been compelled to enforce various preventive measures that include social distancing, lockdown, self-Isolation, quarantine, travel restriction. Although these measures have been effective in checking the spread of the virus, it has also had a profound effect on economic, and social and psychological wellbeing of people (Omang, Angioha, Ojong-Ejoh and Abang, 2020; Hu, Lin, Chiwanda, Kaminga, Xu, 2020;

\footnotetext{
* Corresponding author.

E-mail address: angiohapius@unical.edu.ng (Pius U. Angioha)
} 
Alradhawi, Shubber, Sheppard, \& Ali, 2020). The Socio-economic disruption caused by this measure has been devastating. Tens of millions of individuals are expected to fall into extreme poverty (World Health Organization, 2021; Bamba, Riordan, Ford, \& Matthews, 2020). As of June 2020, the number of undernourished persons was at 690 million, and this figure is expected to increase by another 132 million, (United Nation, 2021; World Health Organization, 2021). Millions of businesses faced going broke, and more than half of the Worlds workforce of 33 billion are at risk of losing their livelihood source (Akintola, Angioha, Abang, Etta, 2020; World Health Organization, 2020). The informal economy which employs more than 2 billion people representing more than 61 per cent of global employment is at risk of losing their jobs (ILO, 2020).

Although Nigeria has had various infectious disease outbreak in its history, none has imposed the kind and nature of social and economic upheaval and dislocation that the SARS-Cov-2 has imposed. Since the index case was reported in February 2020, the number of cases has increased (NCDC, 2020; Akintola, Angioha, Abang \& Etta,2020; Omang \& Angioha, 2020). the county's dilapidated health system, which has been neglected for years, have struggled to cope with the mounting cases. The federal government's directive to curb the virus's spread and save lives has adversely put the masses at risk of different challenges.

According to the United Nations World Food Programme (2020), 80 per cent of people employed in the informal sector have lost their income. With the loss of income and increased food cost, more and more Nigerians are sliding into poverty. The increasing demand from people, loss of revenue, isolation, social distancing, fear of contracting the virus have triggering mental condition and exacerbating existing ones (WHO,2021). Semo and Frissa (2020) argued that the covid 19 pandemic would cause mental health issues that will start early an continue long after the pandemic. Data is sparse, but studies have suggested that the fear of covid-19 pandemic, lockdown, and isolation will lead to delirium, confusion, anxiety, depression (Ditcher, Sanders, Seissman-Peterson \& Kopke, 2020). This study tries to quantitatively analyze the income and mental health impact of Covid-19 pandemic in Calabar.

\section{Theoretical Foundation}

The study adopts the functionalist theory. This theory is attributed to Talcott Parson, Herbart Spencer, Emile Durkheim, and Robert K. Merton. The theory looks at the human society in micro-level orientation, with a broad focus on the social structures that shape the society. The theory sees society as more than its total. For its, society is made up of different structures, with each part or aspect of the structure working for the whole's stability (Parson, 1961; Lenski, 1966). For functionalist, society's various structures are comprised of the family, economy, government, health, education, religion, and mass media. The theory holds that these structures or institutions exist to perform a specific purpose but are inter-dependent (Dunkheim, 1964; Merton, 1966).

For example, the government provides education for children in a family, who pays tax for the government, who also, in turn, provides social services such as hospital and adequate health care. The functionalist theory emphasizes consensus and order. For the theory, disorganization in one social structure leads to change for other structures (Giddens, 1976). The covid-19 pandemic, a health problem, has caused changes to the whole social system, with different structures adjusting for equilibrium. The health system crisis has affected other institutions, such as the family economy, government, and health.

\section{Materials and Methods}

\subsection{Study Area}

Calabar is the capital of Cross River State in the Niger Delta Region of Nigeria. Calabar is located within longitude 80 $17^{\prime} 00 \mathrm{E}$ and $8020^{\prime} 00^{\prime \prime} \mathrm{E}$ and latitudes $4050^{\prime} 00^{\prime} \mathrm{N}$ and $5010^{\prime} 00^{\prime \prime} \mathrm{N}$. The metropolis is made up of two local government area comprising of Calabar South and Calabar Municipality. The area covers an area of $406 \mathrm{~km} 2$. Situated within the tropics, with Odukpani in the North, Akwa Ibom in the south and the Republic of Cameron in the East bordering the area. According to the National Population Census of 2006, the population of Calabar stands at 371, 022 (2006). Calabar is sandwiched between the Calabar River to the West and the Great Kwa to the East. Originally, the area now known as Calabar was inhabited by the Efik, Quas and the Efut. Because of the city's 
position as the Cross-River state's capital and various government parastatals and businesses establishment, the town is now home to multiple tribes (Akpabio, Angioha, Egwuonwo, Awusa, \& Ndujo, 2020).

\subsection{Sampling}

The population of the study includes every individual residing in the study area. According to the last population census, the population of Calabar stands at 371,022 comprising the population of two local government. The sample size of the study is 400 . the sample size is arrived at using the Taro Yamani sample size determinant technique. The cluster, purposive and simple random sampling technique was used in selecting the sample from the study area. Calabar was divided into two clusters according to the two Local Government Areas that make up the area. From these two clusters, five wards were purposively selected each. The wards selected are highlighted in table 1 . These wards were chosen because of easy access. From each of these wards, two streets were also purposively selected. The researcher used the simple random sampling technique to select the study sample from the twenty chosen streets. For every street, the researcher randomly selected one out of every six houses.

\subsection{Instrumentation}

The researcher developed a structured self-developed questionnaire to collect the need information from the study area. The questionnaire contained two sections; each of these sections has its purpose. Section 1 contained information on the respondents' biodata. Section 2 contained questions on the variables raised for the study and was further divided into two subsections according to the variables. The instrument had 13 questions.

\subsection{Ethical Consideration}

A written letter of consent was attached to each of the instrument given to the respondent. This is to support the verbal consent which was obtained before the instrument was given. The anonymity of the response of the respondents was assured.

\subsection{Method of Data Collection and Analysis}

Data for the study was collected with the aid of 4 research assistants, who were taught the ethics and process of data collection. Each of the researcher assistant and the researcher herself were assigned two wards each to distribute the instrument. Data collection process took three weeks. The data collected from the field was coded and entered into the statistical package of social sciences (SPSS). Descriptive statistics such as frequency distribution sample percentages, graphical illustration was used to analyze the data. The descriptive statistics result was then subjected to parametric statistics (Pearson product-moment correlation analysis) at 0.05 confidence level. Out of the 400 instruments distributed, only 379 was returned and used for analysis.

\subsection{Description of Variables}

The objective of the study is to quantitatively analyse the Income, Mental Health Effect of SARS COV-2 Pandemic in Calabar, Cross River State, Nigeria. Specifically, the study

(1) Examine the correlation between SARS COV-2 Pandemic and people's income level in Calabar, Cross River State, Nigeria;

(2) Examine the extent to which SARS COV-2 Pandemic relate to people's mental health in Calabar, Cross River State, Nigeria.

\section{Findings and Discussion}

\subsection{Presentation of Result}

\subsubsection{Objective one}

Examine the correlation between SARS COV-2 Pandemic and people's income level in Calabar, Cross River State, Nigeria. Questions were raised based on this objective and subjected to descriptive analysis such as tables, simple percentages, graphical illustration and frequency distribution. Result is presented in table 1 to 3 and figure 1 to 3 . 
Table 1. Respondents view on Covid-19 pandemic and income Level(N=379)

\begin{tabular}{llccc}
\hline S/N & question & Yes & No & $\begin{array}{c}\text { I don't } \\
\text { know }\end{array}$ \\
\hline 1 & $\begin{array}{l}\text { I had a stable income before the covid 19 pandemic } \\
\text { and curbing measures }\end{array}$ & $254(67.0)$ & $121(31.9)$ & $4(1.1)$ \\
2 & $\begin{array}{l}\text { my income reduced because of the covid 19 and } \\
\text { curbing measures }\end{array}$ & $338(89.2)$ & $41(10.8)$ & $0(0.0)$ \\
3 & $\begin{array}{l}\text { The reduction in my income affected my living } \\
\text { standard }\end{array}$ & $317(83.6)$ & $58(15.3)$ & $4(1.1)$ \\
$4 . \quad \begin{array}{l}\text { My family and I could hardly afford needed family } \\
\text { basics as a result of my income }\end{array}$ & $264(69.7)$ & $83(21.9)$ & $32(8.4)$ \\
\hline
\end{tabular}

I and my family could hardly afford needed family basics as a result of...

The reduction in my income affected my living standard my income reduced because of the covid 19 and curbing measures I had a stable income before the covid 19 pandemic and curbing...

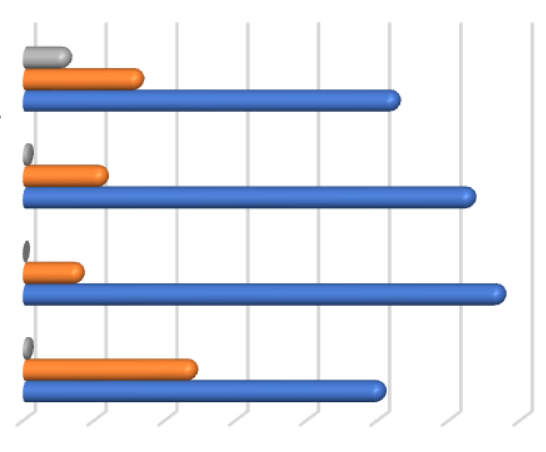

$0 \quad 50100150200250300350$

口I don't Know 日No aYes

Fig. 1 Response of Covi-19 pandemic and income level

Table 2. Respondents by views of how Covid 19 affected income (N=379)

\begin{tabular}{lll}
\hline How Covid-19 Pandemic \& Income & Frequency & Percentage (\%) \\
\hline Loss of jobs & 104 & 27.4 \\
Job Furlough & 32 & 8.4 \\
Reduction in business sales & 46 & 12.1 \\
Reduction in Salary & 67 & 14.0 \\
Shut down of business & 102 & 26.9 \\
Covid 19 didn't affect me & 28 & 7.4 \\
\hline Total & 379 & 100.0 \\
\hline
\end{tabular}




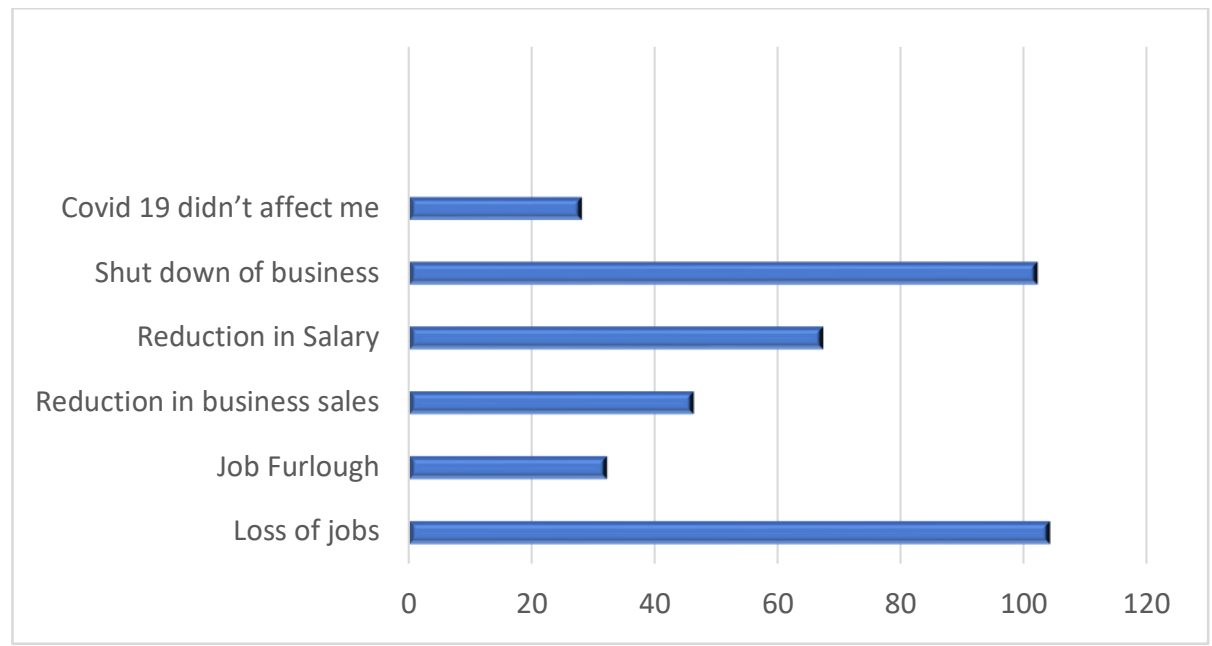

Fig. 2. Response on how COVID-19 affected income

Table 3. Respondents by views of how they survive Covid 19 (N=379)

\begin{tabular}{lll}
\hline Surviving Covid-19 & Frequency & Percentage $(\%)$ \\
\hline Jobs/Business income & 183 & 48.2 \\
Handout from family members & 22 & 5.8 \\
Govt palliatives & 9 & 2.4 \\
Handout from friends & 35 & 9.2 \\
savings & 99 & 26.1 \\
Others & 33 & 8.7 \\
\hline Total & 379 & 100.0 \\
\hline
\end{tabular}

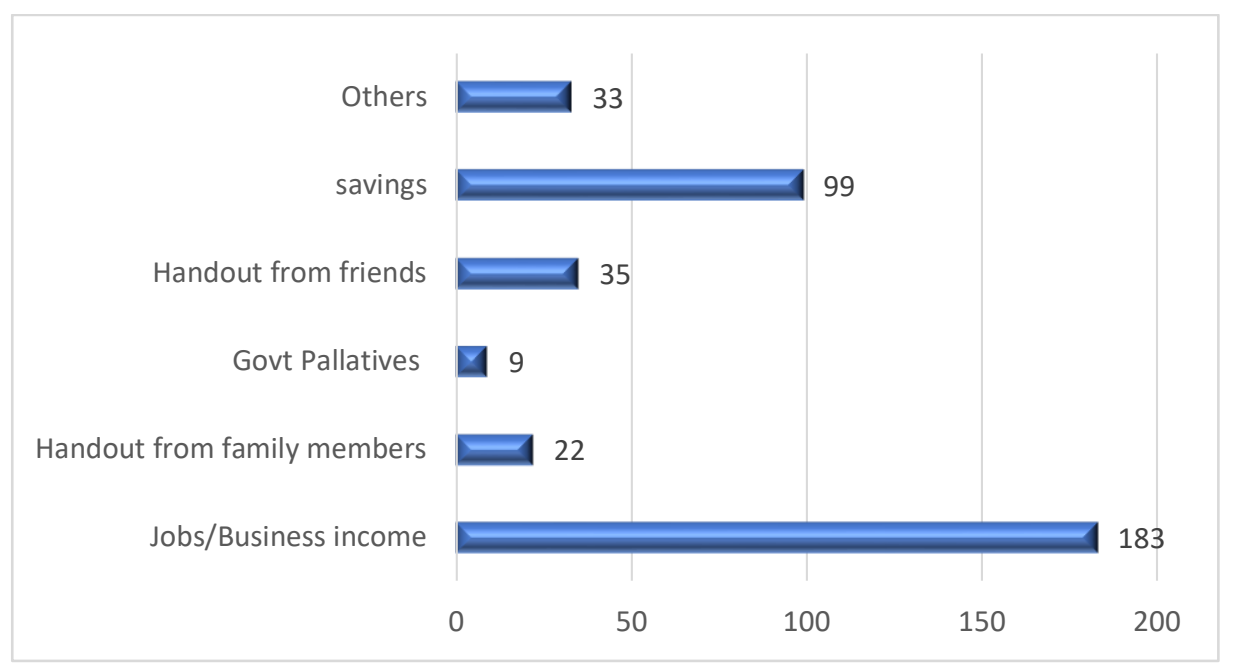

Fig. 3. Response on how respondents survived COVID-19

From the analysis, the result revealed thus; On I had a stable income before the COVID-19 pandemic and curbing measures; 254 respondents representing 67.0 per cent reported Yes, 121, representing 31.9 per cent reported No and 4representing 1.1 per cent reported I don't Know. On, my income reduced because of the COVID-19 and curbing 
measures; 338 respondents representing 89.2 per cent reported Yes, 41, representing 10.8 per cent reported No. On the reduction in my income affected my living standard; 317 respondents, representing 83.6 per cent, reported Yes, 58, representing 15.3 per cent, reported No and 4 respondents representing 1.1 per cent reported I don't know. On my family and I could hardly afford needed family basics due to my income; 264 respondents representing 69.7 per cent reported Yes, 83 respondents representing 21.9 per cent reported No and 32, representing 8.4 per cent reported I don't Know. On how COVID-19 affected income; 104 respondents representing 27.4 reported Loss of Job, 32 representing 8.4 per cent reported Job furlough, 46 representing 12.1 per cent reported reduction in business sales, 67 representing 14 per cent reported a reduction in salary, 102 representing 26.9 per cent reported they shut down business, 28 representing 7.4 reported the pandemic did not affect their income. On how respondents survived during the COVID19 pandemic; 183 respondents representing 48.2 per cent reported Jobs/Business income, 22 representing 5.8 per cent reported handout from family members, 9 representing 2.4 per cent reported government palliatives, 35 representing 9.2 per cent reported handout from friends, 99 representing 26.1 per cent reported from savings, and 33 representing 8.7 reported others.

The result from the descriptive analysis was subjected to parametric statistic (Pearson Product Moment Correlation) at 0.05 confidence level. The independent variable in the analysis is Covid-19 pandemic, while the dependent variable is Income Level. Pearson product-moment correlation coefficient was used to test the analysis at 0.05 level of significance and the result is presented in Table 4.

Table 4. Pearson product-moment correlation of Covid-19 and Income Level

\begin{tabular}{lccccc}
\hline Variable & $\mathrm{N}$ & Mean & SD & r-value & Sig. \\
\hline Covid-19 & 379 & 13.07 & 1.97 & $0.324^{* *}$ & .000 \\
Income Level & 379 & 12.07 & 1.95 & & \\
\hline
\end{tabular}

*significant at 0.05 level; $\mathrm{df}=377$; critical $\mathrm{r}$ value $=0.098$

The result in Table 4 revealed that the calculated $\mathrm{r}$-value of $0.324^{* *}$ is greater than the critical $\mathrm{r}$-value of 0.098 at 0.05 level of significance with 377 degrees of freedom. By this result, the null hypothesis which states that there is no significant correlation between Covid-19 pandemic and income level of people in Calabar, Cross River State, Nigeria, is rejected while the alternate hypothesis is accepted. The correlation coefficient is a standardised measure of an observed effect. It is a commonly used measure of the size of an impact. The values of \pm .1 represent a small effect, \pm .3 is a medium effect, and \pm .5 is a significant effect.

The squared correlation $(0.324)^{2}$, a measure of effect size indicates the proportion of explained variance on the dependent variable. Therefore, $10.4 \%$ of the variance in income level is accounted for by Covid-19. The magnitude of effect is moderate, which means that the Covid-19 pandemic has significantly affected the study area's income level. Therefore, we can conclude a statistical considerable correlation between Covid-19 pandemic and people's income level in Calabar, Cross River State, Nigeria.

\subsubsection{Objective two}

Examine the effect of SARS COV-2 Pandemic relate to people's mental health in Calabar, Cross River State, Nigeria. Questions were raised based on this objective and subjected to descriptive analysis such as tables, simple percentages, graphical illustration and frequency distribution. Result is presented in table 5 and figure 4.

Table 5. Respondents view on Covid-19 pandemic and mental Health ( $\mathrm{N}=379)$

\begin{tabular}{llccc}
\hline S/N & \multicolumn{1}{c}{ Item } & Yes & No & $\begin{array}{c}\text { I don't } \\
\text { Know }\end{array}$ \\
\hline 1. & I was not happy throughout the lockdown & $278(73.4)$ & $92(24.3)$ & $9(2.4)$ \\
2 & $\begin{array}{l}\text { I lived in constant fear of contacting covid 19 } \\
\text { during the lockdown }\end{array}$ & $243(64.1)$ & $136(35.9)$ & $22(5.8)$ \\
3. & It affected me mentally & $98(25.9)$ & $200(52.8)$ & $81(21.4)$ \\
4 & I was depressed during the lockdown & $157(41.4)$ & $181(47.8)$ & $41(10.8)$ \\
\hline
\end{tabular}




\begin{tabular}{llccc}
\hline S/N & \multicolumn{1}{c}{ Item } & Yes & No & $\begin{array}{c}\text { I don't } \\
\text { Know }\end{array}$ \\
\hline 5 & $\begin{array}{l}\text { I needed to see the doctor during the lockdown } \\
\text { because of my mental health }\end{array}$ & $54(14.2)$ & $325(85.8)$ & $0(0.00)$ \\
6 & $\begin{array}{l}\text { I had issues with family members during the } \\
\text { lockdown }\end{array}$ & $278(73.4)$ & $101(26.6)$ & $0(0.00)$ \\
7 & $\begin{array}{l}\text { As a result of me not been able to meet the needs } \\
\text { of my family I fell sick }\end{array}$ & $121(31.9)$ & $258(68.1)$ & $0(0.00)$ \\
\hline
\end{tabular}

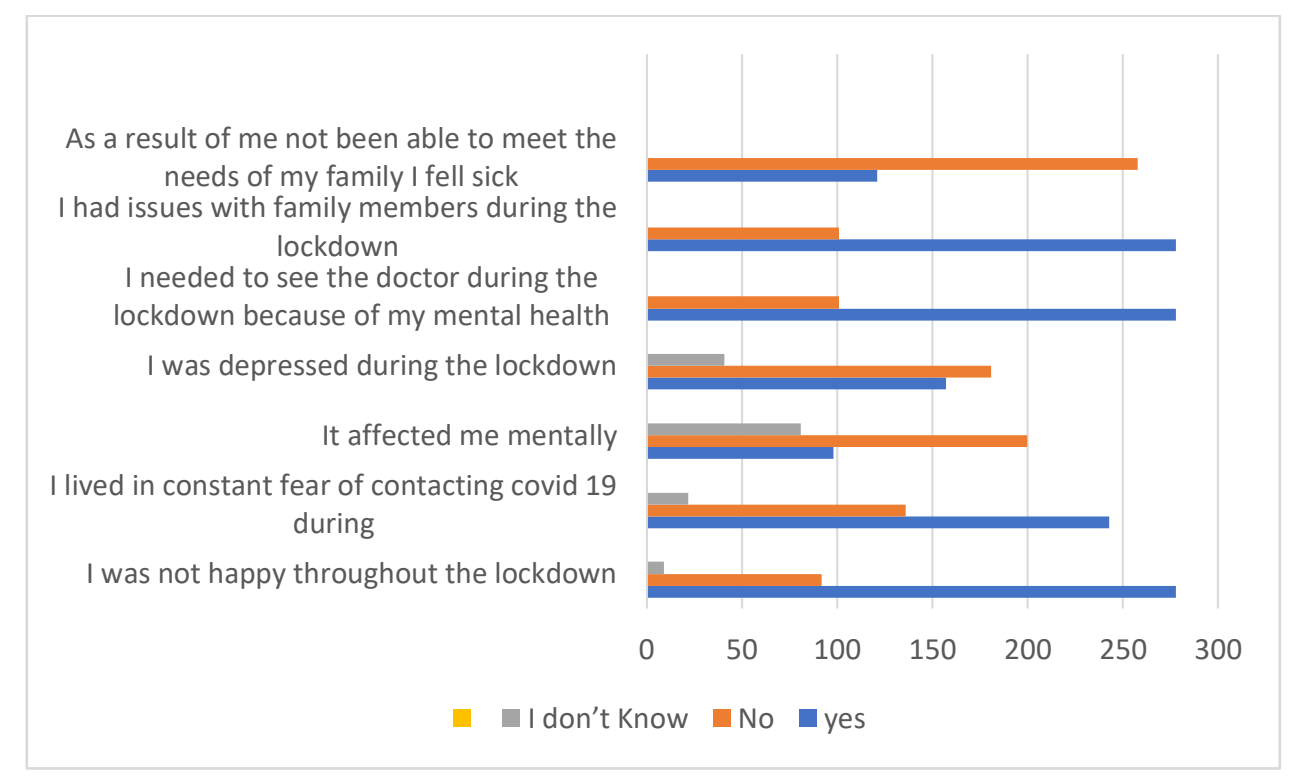

Fig. 4. Response on Covid-19 pandemic and mental health

From the analysis, the result revealed thus; On I was not happy throughout the lockdown, 278 respondents representing 73.4 per cent reported Yes, 92 representing 24.3 per cent reported No and 9 representing 2.4 per cent reported I don't Know. On I lived in constant fear of contacting covid 19 during the lockdown; 243 representing 64.1 per cent reported Yes, 136 representing 35.9 per cent reported No and 22 representing 5.8 per cent reported I don't Know. On It affected me mentally; 98 respondents representing 25.9 per cent reported Yes, 200 representing 52.8 per cent reported No and 81 representing 21.4 per cent reported I don't Know. I was depressed during the lockdown; 157 representing 41.4 per cent reported Yes, 181 representing 47.8 per cent reported No and 41 representing 10.8 per cent reported I don't Know. On I needed to see the doctor during the lockdown because of my mental health; 54 respondents representing 14.2 per cent reported Yes, and 325 representing 85.8 per cent reported No. On I had issues with family members during the lockdown; 278 respondents representing 73.4 per cent reported Yes and 258 representing 68.1 per cent reported No. As a result of me not meeting my family's needs, I fell sick; 121 respondents representing 31.9 per cent reported Yes, and 258, representing 68.1 per cent reported No.

The result from the descriptive analysis was subjected to parametric statistic (Pearson Product Moment Correlation) at 0.05 confidence level. The independent variable is Covid-19 pandemic, while the dependent variable is mental health. Pearson product-moment correlation coefficient was used to test this hypothesis at 0.05 level of significance, and the result is presented in Table 6. 
Table 6. Pearson product-moment correlation of Covid-19 pandemic and mental health

\begin{tabular}{llllll}
\hline Variable & $\mathrm{N}$ & Mean & SD & r-value & Sig. \\
\hline Covid-19 pandemic & 379 & 13.83 & 2.07 & & \\
& & & & $-0.252^{* *}$ & .000 \\
mental health & 379 & 12.07 & 1.95 & & \\
\hline$*$ significant at 0.05 level; $d f=377$; critical $r$ value $=0.098$ & & &
\end{tabular}

The result in Table 6 revealed that the calculated r-value of $-0.252^{* *}$ is greater than the critical $\mathrm{r}$-value of 0.098 at 0.05 level of significance with 377 degrees of freedom. By this result, the null hypothesis states that Covid-19 pandemic does not significantly relate to people's mental health in Calabar, Cross River State, Nigeria, is rejected while the alternate hypothesis is accepted.

The squared correlation $(0.252)^{2}$ known as the coefficient of determination, which is used as a measure of effect size indicates the proportion of explained variance on the dependent variable. Therefore, $6.3 \%$ of the variance in mental health is accounted for by the Covid-19 pandemic. The magnitude of effect is negligible. By this result, we can conclude that the covid 19 pandemic has had a considerable impact on Calabar's mental health.

\subsection{Discussion of Findings}

From the analysis carried from the data collected from the field, it was discovered that most of the respondents were male $(60.4 \%)$, and most of them (67.2\%) were between the ages of 18 and 40 years. In terms of education, 48.8 per cent had at least a first degree, and a majority of them (36.1\%) were civil servants, 12 per cent of the respondents were traders, and with the presence of several higher institutions in the area, we had 21.6 per cent who were students. The area being in the southern part of the nation, most of the respondents $(92.3 \%)$ were Christians.

The lockdown and other measures to fight the spread of the disease meant people staying at home. From the descriptive analysis carried out on the first objective, 89.2 per cent of the respondents reported a reduction in their income due to the Covid-19 pandemic. 83.6 per cent of the respondents said they struggled to survive during the pandemic due to income loss. According to the respondents, the reduced income was; 27.4 per cent loss of job, 26.9 per cent shut down of business, 14 per cent reduction in salary, 12.1 per cent reduced sales and 8.4 per cent furlough, 26.1 per cent reported surviving on their savings during the lockdown. Some $(9.2 \%)$ had to survive from friends and (5.8\%) family members. The result from the descriptive analysis was then subjected to parametric statistics at 0,05 confidence level. The result revealed a statistical considerable correlation between Covid-19 pandemic and people's income level in Calabar, Cross River State, Nigeria. This is because the calculated r-value of $0.324 * *$ is greater than the critical r-value of 0.098 at 0.05 level of significance with 377 degrees of freedom. Also, the squared correlation $(0.324)^{2}$, which is a measure of effect size, indicates the proportion of explained variance on the dependent variable. Therefore, $10.4 \%$ of the variance in income level is accounted for by Covid-19. The study thereby concludes that the covid-19pandemic has a significant impact on people's income in the study area. This finding is corroborated by that of Tran, Nguyen, Le, Latkin, and Pham (2021) found that among 341 participants, 66.9 per cent report household income loss from the covid-19. Kalil, Mayer and Shah (2020) found that family income has significantly reduced due to the covid-19, resulting in associate illness. Dias and Mahrt (2020) revealed that family income fell considerably for rural and urban households due to the pandemic.

On mental health evidence shows that psychologically, the pandemic has affected people's mental health in the study area; 25.9 per cent of the respondents reported so. 41.4 per cent also reported being depressed during pandemic lockdown. Some of the respondents (14.2\%) reported needing to see the doctor during the lockdown. 31.9 per cent reported falling sick due to not being able to meet the needs of their family. Also, the result from the descriptive analysis was subjected to parametric statistics at 0.05 confidence level. The result revealed that the covid 19 pandemic has had a considerable impact on Calabar's mental health. This is because the calculated $\mathrm{r}$-value of $-0.252^{* *}$ is greater than the critical r-value of 0.098 at 0.05 level of significance with 377 degrees of freedom. Also, the squared correlation $(0.252)^{2}$ known as the coefficient of determination, which is used as a measure of effect size indicates the proportion of explained variance on the dependent variable. Therefore, $6.3 \%$ of the variance in mental health is accounted for by the Covid-19 pandemic. by this, the study concludes that the covid-19pandemic has had a 
considerable impact on people's mental health in the study area. This finding is supported by that of Sharma, and Joshi (2020). They reviewed various articles on the mental health impact of covid-19 on adolescent and found that that covid-19 pandemic has significantly impacted children's mental health. Braquehais, Vargas-Cáceres, Gómez-Durán, Nieva, Valero, Casas, and Bruguera (2020) analysed various studies and found that prevalence of anxiety and depression symptom among health professional. Rajkumar (2020) found a significant correlation between covid-19 and mental health. Vindegaard and Beinros (2020) found a significant effect of covid-19 on level of depression

\section{Conclusion and recommendation}

This study aimed to examine the correlation between covid-19 pandemic and socio-economic life of people in Calabar, cross river state. From the analysis carried out, the result revealed that the covid-19 pandemic has significantly impacted family income and mental health of people in Calabar, cross river state. Based on this finding, the study recommends that the Nigerian government implement changes in their social security programmes to meet the needs of vulnerable in society. During times such as these and other crisis, the state government and Nigerian government needs to harness and improve on micro-credit schemes that will provide soft loans for low-income earners without a lot of bureaucratic bottlenecks and stringent processes, and there is need for government and its relevant health agencies to provide guidance and advice during this period for health workers, general public, people for isolation to help them deal with their mental health.

\section{References}

Akintola, A. I., Angioha, P. U., Abang, T. \& Etta, E. (2020). COVID 19 Pandemic and Entrepreneurship Enterprise in Calabar, Cross River State, Nigeria. Conference Proceedings of the 2020 Virtual International Conference of the Research Centre for Management and Social Studies. 1, 177-183

Akpabio, U., Angioha, P. U., Egwuonwu, C. V., Awusa, E. B., \& Ndiyo, M. N. (2020). Risk Factors of Maternal Mortality in Calabar. JINAV: Journal of Information and Visualization, 1(2), 83-92. https://doi.org/10.35877/454ri.jinav262

Alradhawi, M., Shubber, N., Sheppard, J., \& Ali, Y. (2020). Effects of the COVID-19 pandemic on mental wellbeing amongst individuals in society- A letter to the editor on "The socio-economic implications of the coronavirus and COVID-19 pandemic: A review". International Journal of Surgery, 78. https://doi.org/10.1016/j.ijsu.2020.04.070

Amawi, H., Abu Deiab, G. I., A Aljabali, A. A., Dua, K., \& Tambuwala, M. M. (2020). COVID-19 pandemic: an overview of epidemiology, pathogenesis, diagnostics and potential vaccines and therapeutics. Therapeutic delivery, 11(4), 245-268. https://doi.org/10.4155/tde-2020-0035

Bambra, C., Riordan, R., Ford, J., \& Matthews, F. (2020). The COVID-19 pandemic and health inequalities. Journal of Epidemiology and Community Health, jech-2020. https://doi.org/10.1136/jech-2020-214401

Binns, C., Low, W. Y., \& Kyung, L. M. (2020). The COVID-19 Pandemic: Public Health and Epidemiology. Asia Pacific Journal of Public Health, 32(4), 140-144. https://doi.org/10.1177/1010539520929223

Braquehais, M. D., Vargas-Cáceres, S., Gómez-Durán, E., Nieva, G., Valero, S., Casas, M., \& Bruguera, E. (2020). The impact of the COVID-19 pandemic on the mental health of healthcare professionals. QJM : monthly journal of the Association of Physicians, hcaa207. Advance online publication. https://doi.org/10.1093/qjmed/hcaa207

Diao, X., \& Mahrt, K. (2020). Assessing the Impacts of COVID-19 on Household Incomes and Poverty in Myanmar. A microsimulation approach. Myanmar Strategy Support Program Working Paper 02. Yangon: International Food Policy Research Institute. 
Dichter, M. N., Sander, M., Seismann-Petersen, S. \& Kopke, S.(2020). COVID-19: it is time to balance infection management and person-centered care to maintain mental health of people living in German nursing homes. International Psychogeriatrics. doi: 10.1017/

Hu, Z., Lin, X., Chiwanda Kaminga, A., \& Xu, H. (2020). Impact of the COVID-19 Epidemic on Lifestyle Behaviors and Their Association With Subjective Well-Being Among the General Population in Mainland China: Cross-Sectional Study. Journal of medical Internet research, 22(8), e21176. https://doi.org/10.2196/21176

International Labor Organization (2020). More than 60 per cent of the world's employed population are in the informal economy. https://www.ilo.org/global/about-the-ilo/newsroom/news/WCMS 627189/lang-en/index.htm\#: :text=The\%20report\%20shows\%20that\%2093,over\%20740\%20million\%20are\%20women.

Janssens, W., Pradhan, M., de Groot, R., Sidze, E., Donfouet, H. P. P., \& Abajobir, A. (2021). The short-term economic effects of COVID-19 on low-income households in rural Kenya: An analysis using weekly financial household data. World Development, 138, 105280. https://doi.org/10.1016/j.worlddev.2020.105280

Kalil, A., Mayer, S., \& Shah, R. (2020). Impact of the COVID-19 Crisis on Family Dynamics in Economically Vulnerable Households. SSRN Electronic Journal, 1. https://doi.org/10.2139/ssrn.3705592

Karasmanaki, E., \& Tsantopoulos, G. (2021). Impacts of social distancing during COVID-19 pandemic on the daily life of forestry students. Children and youth services review, 120, 105781. https://doi.org/10.1016/j.childyouth.2020.105781.

Lenon, O, (2020). What is the economic impact of COVID-19 in Nigeria? https://www.cdcgroup.com/en/newsinsight/insight/articles/what-is-the-economic-impact-of-covid-19-in-nigeria/

Lenski, G. (1966). "Power and Privilege: A Theory of Social Stratification." New York: McGraw-Hill.

Merton, R.K. (1968b), 'Manifest and latent functions' in Social Theory and Social Structure. Free Press: New York.

Muralidar, S., Ambi, S. V., Sekaran, S., \& Krishnan, U. M. (2020). The emergence of COVID-19 as a global pandemic: Understanding the epidemiology, immune response and potential therapeutic targets of SARSCoV-2. Biochimie, 179, 85-100. https://doi.org/10.1016/j.biochi.2020.09.018

National Bureau of Statistics (2020). COVID-19 National Longitudinal Phone Survey 2020. https://microdata.worldbank.org/index.php/catalog/3712

Nigeria Centre for Disease Control. (2020). Covid-19 Situation Report. Abuja.. https://ncdc.gov.ng/themes/common/files/sitreps/77340252cece5b82edd43f713ee215f9.pdf._

Nigeria Centre for Disease Control. (2021). Available from: https://covid19.ncdc.gov.ng/state/.

Olaseni, A. O., Akinsola, O. S., Agberotimi, S. F., \& Oguntayo, R. (2020). Psychological distress experiences of Nigerians during Covid-19 pandemic; the gender difference. Social Sciences \& Humanities Open, 2(1), 100052. https://doi.org/10.1016/j.ssaho.2020.100052

Omang, T. A., \& Angioha, P. U. (2021). Assessing the Impact Covid-19 Pandemic on the Educational Development of Secondary School Students. JINAV: Journal of Information and Visualization, 2(1), 25-32. https://doi.org/10.35877/454RI.jinav261

Omang, T. A., Angioha, P. U., Ojong-Ejoh, M. U. \& Abang, T. (2020). Covid-19 Measures and the Exacerbation of Intimate Partner Violence in Calabar, Ijo- International Journal Of Social Science And Humanities Research., 3(12)83-94

Parsons, T., (1961) Theories of Society: foundations of modern sociological theory, Free Press, New York

Piyapromdee, S., \& Spittal, P. (2020). The Income and Consumption Effects of COVID-19 and the Role of Public Policy*. Fiscal Studies, 41(4), 805-827. https://doi.org/10.1111/1475-5890.12252 
Semo, B.-, \& Frissa, S. M. (2020). The Mental Health Impact of the COVID-19 Pandemic: Implications for SubSaharan Africa. psychology Research and Behavior Management, Volume 13, 713-720. https://doi.org/10.2147/prbm.s264286

Tran, B. X., Nguyen, H. T., Le, H. T., Latkin, C. A.\& Pham, H. Q., (2020). Impact of COVID-19 on Economic WellBeing and Quality of Life of the vietnamese during the National Social Distancing. Frontiers in Psychology, 11, 1-9. https://doi.org/10.3389/fpsyg.2020.565153

United Nation (2020). Women: COVID-19 and Ending Violence Against Women and Girls https://www.unwomen.org/-/media/headquarters/attachments/sections/library/publications/2020/issue-briefcovid-19-and-ending-violence-against-women-and-girls-en.pdf?la=en\&vs=5006

Vindegaard, N., \& Benros, M. E. (2020). COVID-19 pandemic and mental health consequences: Systematic review of the current evidence. Brain, behavior, and immunity, 89, 531-542. https://doi.org/10.1016/j.bbi.2020.05.048

World Economic Forum (2020). Here's how COVID-19 has battered Africa's largest economy. https://www.weforum.org/agenda/2020/08/africa-largest-economy-worst-contraction-in-a-decade/

World Health Organisation (2021). WHO Coronavirus Disease (COVID-19) Dashboard. Situation by Country, Territory \& Area. https://covid19.who.int/table

World Health Organization (2021). COVID-19 disrupting mental health services in most countries, WHO survey. https://www.who.int/news/item/05-10-2020-covid-19-disrupting-mental-health-services-in-most-countrieswho-survey

World Health Organization (WHO). (2020). Novel coronavirus (2019-nCoV) situation report - 121 January 2020. WHO Bull. 2020:1-7 https://www.who.int/emergencies/diseases/novel-coronavirus2019? gclid=CjwKCAiAsOmABhAwEiwAEBROZn5Gu4UTYtfkvOx4v7Ti2f6 jYzKuzHuthbPOaejnUv2nXWx UbJbghoCJ6gQAvD_BwE 